\title{
The Common European Framework of Reference from the perspective of English as a lingua franca: : what we can learn from a focus on language regulation
}

\section{Hynninen, Niina}

2014

Hynninen, N 2014 , ' The Common European Framework of Reference from the perspective of English as a lingua franca: what we can learn from a focus on language regulation ', Journal of English as a Lingua Franca, vol. 3 , no. 2 , pp. 293-316 . https://doi.org/10.1515/jelf-2014-0018

http://hdl.handle.net/10138/230258

https://doi.org/10.1515/jelf-2014-0018

publishedVersion

Downloaded from Helda, University of Helsinki institutional repository.

This is an electronic reprint of the original article.

This reprint may differ from the original in pagination and typographic detail.

Please cite the original version. 
Niina Hynninen

\title{
The Common European Framework of Reference from the perspective of English as a lingua franca: what we can learn from a focus on language regulation
}

\begin{abstract}
This paper discusses the Common European Framework of Reference for Languages (CEFR) in relation to research conducted on English as a lingua franca (ELF). The following aspects will be considered: (a) the native speaker and native language culture foci particularly of the proficiency level descriptors in the CEFR, and why they are conceptually problematic from an ELF perspective, and (b) the ways ELF speakers have been found to regulate language in ELF interaction (e.g., by correcting and commenting on language) and how the regulation can be seen to construct alternative norms for English used in lingua franca settings. The paper seeks answers to McNamara's (2012) call for articulating the construct of ELF communication in a way that it can act as the focus for the assessment of English. It will be argued that a crucial aspect in reaching this goal is to reconsider some of the fundamental assumptions of language use presented in the CEFR. This includes not only moving beyond native speaker-non-native speaker contacts and the idea of a native speaker target culture, but also moving towards more context-aware assessment criteria, which would be informed by research on language regulatory practices in ELF interaction.
\end{abstract}

Keywords: Common European Framework of Reference for Languages, English as a lingua franca, language regulation, assessment

\section{Eurooppalainen viitekehys englanti lingua francana- näkökulmasta: mitä kielensäätelyn tutkiminen voi meille opettaa}

Tiivistelmä: Tässä artikkelissa tarkastellaan Eurooppalaista viitekehystä suhteessa englanti lingua francana (ELF) -tutkimukseen. Aihetta käsitellään seuraavista näkökulmista: (a) miten ja miksi etenkin Viitekehyksen taitotasot, jotka korostavat kommunikaatiota äidinkielisten puhujien kanssa ja äidinkielisiin liitetyn

Niina Hynninen: University of Helsinki. E-mail: niina.hynninen@helsinki.fi 
kulttuurin tärkeyttä, ovat käsitteellisesti ongelmallisia ELF-näkökulmasta katsottuna, ja (b) miten ELF-puhujat säätelevät kieltä vuorovaikutustilanteissa (esim. korjaamalla toistensa kieltä tai kommentoimalla kieltä) ja miten tämän säätelyn voidaan katsoa rakentavan vaihtoehtoisia kielellisiä normeja ELF-tilanteissa. Artikkelissa pyritään vastaamaan McNamaran (2012) esittämään tarpeeseen kielentää ELF-kommunikaation periaate tavalla, joka mahdollistaa sen käyttämisen englannin kielen testauksen lähtökohtana. Tämän tavoitteen saavuttamiseksi on olennaista tarkastella uudelleen Viitekehyksessä esitettyjä perusoletuksia kielen käytöstä. Artikkelissa esitetään, että tämä tarkoittaa myös muunlaisten kontaktien kuin äidinkielisten ja ei-äidinkielisten välisten kontaktien huomioon ottamista sekä äidinkielisiin sidotun kohdekulttuurin ajatuksen purkamista. Lisäksi olisi tärkeää luoda arviointikriteerejä, jotka ottaisivat paremmin huomioon kielenkäyttökontekstin ja jotka rakentuisivat osin sen varaan, mitä tutkimukset osoittavat kielensäätelykäytännöistä ELF-vuorovaikutuksessa.

Avainsanat: Eurooppalainen viitekehys, englanti lingua francana, kielen säätely, arviointi

\section{Introduction}

In Europe, the Common European Framework of Reference for Languages (CEFR; Europe 2001) has come to frame language education policy. It has been stated that "nobody engaged in language education in Europe can ignore the existence of the CEFR" (Alderson 2007: 660), and that in terms of the CEFR, "the kind of influence on actual practices that can be exerted from the top down has largely been exhausted" (Byrnes 2007: 681). What is more, it now seems that the influence of the CEFR reaches beyond the borders of Europe (Leung 2013). But to what extent is this framework applicable for English used as a lingua franca?

The CEFR was developed by an international expert team under the aegis of the Council of Europe. It is a general framework for all languages, intended to include "a descriptive scheme for analysing what is involved in language use and language learning" (Little 2007: 645-656). The framework defines six levels of communicative proficiency that reflect an individual's language competence (basic user levels A1 = Breakthrough, and A2 = Waystage; independent user levels B1 = Threshold, and B2 = Vantage; and proficient user levels C1 = Effective operational proficiency, and C2 = Mastery). What is notable, then, is that, first, the CEFR is not language specific, but rather functions language independently, 
with the aim of being applicable for learners and users of any foreign language. Second, the CEFR is a general framework that includes context-free proficiency level descriptors. It is intended to be as comprehensive as possible, while at the same time open and dynamic (Europe 2001: 8). In fact, the Council of Europe has encouraged users to adapt the framework to reflect local needs and contexts.

The strength of the CEFR lies in its approach to language learning and assessment, which promotes a common understanding of current concepts in second language acquisition (Pilkinton-Pihko 2013: 81). Particularly the proficiency level descriptors have been (and still are) an influential part of the framework. In fact, the descriptors quickly appealed to language testing agencies that interpreted the six-level scale as a ready means not only to indicate the degree of a test taker's communicative proficiency but also as a means to compare tests to one another (Little 2007). However, despite the tremendous influence the CEFR has had on language education, the framework is not without its critics.

What strikes me as a particularly important critique is the concern that has been raised about the atheoretical nature of the CEFR descriptors; that is, that the descriptors are based on the common perception of teachers, rather than on theories of language and interaction (e.g., Fulcher 2004; see also Little 2007; North 2007). In fact, the CEFR descriptors were calibrated based on language teachers' and other experts' judgments rather than on empirical evidence from language learner data, which means that the CEFR lacks empirical support for what is minimally required for performance at a certain level (Hulstijn 2007). In addition, the general nature of the framework and the context-free descriptors have stirred a debate about the applicability of the CEFR to specific contexts. While the context-independent nature of the CEFR can be seen as a necessary idealisation concerning the overall purpose of the framework, this has been found to limit the applicability of the framework to language for specific purposes contexts (e.g., Toepfer and Virkkunen-Fullenwider 2005; PilkintonPihko 2013).

On a related note, we can also argue that developments in the use of English as a lingua franca (ELF) raise new questions about the generalisability of the CEFR to all languages. For instance, Pilkinton-Pihko (2013) illustrates the prominence of specific native speaker (NS) language ideologies in the CEFR, which, she concludes, limit the ability of applying the framework to ELF contexts. Other ELF researchers have also criticised the CEFR particularly in terms of the NS focus of the descriptors (Seidlhofer 2003; McNamara 2012; Leung 2013). It is not surprising that the construct of ELF is absent from the CEFR - given that its roots date back to a time when the use of ELF had not come to prominence. In addition, considering the language-independent nature of the CEFR, we cannot 
assume that the document would address all the difficulties in applying the framework for specific languages that may require special treatment. However, today, when non-native users of English outnumber its NSs (e.g., Graddol 2006), lingua franca use of English is highly relevant, and consequently the construct of ELF important in discussing implications for English language education. For this reason, it is also important to consider the CEFR from an ELF perspective, and to consider the limitations of the framework when dealing with ELF communication. This is particularly so if we think about the influential status of the framework, and the calls for empirical studies to connect developmental routes in second language acquisition with language assessment (e.g., Hulstjin 2007).

\section{Previous research on ELF}

Seidlhofer (2003: 11) has suggested that for European language education, ELF needs to be considered "an alternative option to ENL [English as a native language] in some contexts and as the default option in others." ${ }^{1}$ The suggestion is based on the changing role of English in Europe and beyond, and it is discussed from four perspectives: from a functional, conceptual, linguistic, and pedagogical perspective. According to Seidlhofer, functionally, the current role of English in the world is generally acknowledged, but the conceptually interesting question is whether "ways of thinking about English have kept pace with the rapid development in the functions of the language" (2003: 12). Research shows that some evidence does exist of changes in both language learner and user attitudes towards English (e.g., Jenkins 2007; Kankaanranta and Louhiala-Salminen 2010; Ranta 2010). In addition, it seems that what speakers treat as acceptable English in ELF interactions may very well differ from our traditional understanding of what such English is like, and importantly, it appears that experience in ELF use also reduces the weight speakers attach to traditional assumptions of correctness (Hynninen 2013; see also Ehrenreich 2009; Kalocsai 2009; PilkintonPihko 2013).

A decade after Seidhofer's (2003) publication, we have seen an abundance of descriptive ELF research, which has contributed to our understanding of the linguistic side of the matter (for an overview, see Jenkins et al. 2011). These studies, which have mainly focused on spoken ELF, report on patterns in ELF interaction

1 Seidlhofer (2003) uses the term English as an international language (EIL) rather than ELF, but since the established term today is ELF, this is also the term adopted here. 
that differ from corresponding English NS interaction. Particularly, certain types of non-standard lexicogrammatical features seem to be found repeatedly in ELF interaction (see Seidlhofer 2004; Björkman 2008; Cogo and Dewey 2012), which means that we cannot dismiss the findings as arbitrary mistakes. It also seems that some of these non-standard features are actually shared with vernacular varieties and postcolonial varieties of English (Ranta 2009, 2013). Research on ELF has also considered spoken language processing from the perspective of idioms (Pitzl 2009, 2012) and phraseological units (Mauranen 2009, 2010, 2012; see also Carey 2013). Pitzl $(2009,2012)$ states that in ELF settings, there is a possibility to reintroduce metaphor into idiomatic language; that idioms which are typically conventionalised and fixed are less likely to be that in ELF than in ENL settings. Mauranen's (2009, 2010, 2012) findings similarly illustrate that phraseological units in ELF may have approximate, non-standard forms, but the further point that Mauranen makes is that preference patterns seem to emerge, suggesting holistic processing of the units. In addition to lexicogrammatical features of ELF, there is an abundance of research on the pragmatics of ELF (e.g., see Björkman 2011), with much of the research dealing with the importance of accommodation for successful ELF communication (e.g., Jenkins 2000; Deterding and Kirkpatrick 2006; Cogo and Dewey 2006; Cogo 2009), and some studies also discussing the question of culture and ELF (e.g., Meierkord 2002; Baker 2009). All these studies include pedagogical implications. Many of the studies emphasise the importance of being able to negotiate language in interaction, and the importance of reconsidering what (or who) the language learning model should be, which will be discussed further later on in this paper.

Importantly, ELF has also been noticed in language assessment circles. McNamara (2012) argues that for language assessment to take ELF into account, two aspects are central: (a) to articulate the construct of ELF communication in a way that it can be formulated in standards that can then act as the focus of assessment, and (b) to conceptualise a learning dimension in ELF communication. My purpose in this paper is to consider these questions in the light of recent developments in ELF research. While I do not claim to solve the questions, I will suggest some principles that need to be taken into account when considering them. This will be done (a) by analysing the CEFR as a whole, with particular focus placed on the types of contacts articulated in the framework, that is, who language learners are expected to communicate with, and what language norms the learners seem to be expected to follow, and (b) by drawing on research done on language regulation in ELF (particularly Hynninen 2013) to discuss what speakers construct as acceptable language in interaction, and how we may need to broaden our understanding of language standards to assess the success of ELF communication. 


\section{Language regulation in communities of practice}

Previous research has illustrated the need to modify the CEFR descriptors to suit different contexts (e.g., Toepfer and Virkkunen-Fullenwider 2005; PilkintonPihko 2013). This research, taken together with the encouragement of the Council of Europe to adapt the descriptors to local contexts, suggests that there is a need to develop more context-aware language assessment criteria. My argument here is that one way of doing this is to approach the question from a community of practice (Lave and Wenger 1991) point of view. Because my focus in this paper is on the applicability of the CEFR to ELF contexts, this discussion, too, deals with particularly ELF communities of practice, even if the question of context-awareness is important beyond assessing competence to use ELF.

While the spread of English is a global phenomenon, it is important to remember that users of ELF do not form a single community, but rather many (Haberland 2011). ELF is spoken in different contexts with different conditions. Added to this is what some scholars have called the "fluidity" of ELF, which is often depicted as "ad hoc situated negotiation of meaning" (Seidlhofer 2009: 242) or is used in reference to "ever-changing negotiated spaces" (Pennycook 2012: 143) emphasising the flexibility required from speakers when moving from one ELF encounter (or community) to the next. The lack of a single community and the fluidity of ELF may be problematic for the description of commonalities in ELF (be they linguistic features or pragmatic elements), but it seems to me that we need to realise that while some ELF encounters can certainly be described as fluid, if we focus on ELF encounters in a specific community of practice, or groups of people who come together around a mutual aim, we begin to see patterns in the fluidity. ${ }^{2}$ In addition, corpus studies conducted on ELF have illustrated recurrent lexicogrammatical features in ELF that suggest patterns that go beyond ad hoc encounters (notably research conducted on the ELFA corpus of ELF in academic settings, such as Mauranen 2007, 2012; Metsä-Ketelä 2006 and Ranta 2009).

What we can learn from studies focusing on ELF use in communities of practice (e.g., Ehrenreich 2009; Kalocsai 2009; Smit 2010; Björkman 2013; Hynninen 2013) are local realisations and perceptions of ELF. The concept of community of practice thus provides us with a means to conceptualise communal practices and

2 The concept of community of practice, which originates in the work of Lave and Wenger (1991; see also Wenger 1998), has been widely adopted in ELF research in order to shift attention from more rigid discourse communities towards groups of people who come together around a mutual aim. Among the first studies to suggest using the concept in ELF studies is House (2003). Further discussions about the concept and its usefulness for ELF include Seidlhofer (2007), Dewey (2009), Ehrenreich (2009), and Hynninen (2013). 
norms. ${ }^{3}$ The findings may not necessarily be generalisable across other contexts, but they give us an idea about the ways speakers negotiate English in the community of practice, and they also have the potential to shed light on the language learning dimension in ELF (i.e., in what ways do the expert members of a community of practice use language and what do they teach or expect from the novices). Such investigations raise further questions about the regulation of language and the relevance or irrelevance of established language standards in specific communities of practice (Hynninen 2013), and what users of ELF require for performance that is adequate in terms of communicative functioning. For instance, Ehrenreich's (2009) ethnographic study of business ELF communities of practice suggests that, for the business professionals, the

process of being socialized into international business CofPs [i.e., communities of practice] involves leaving behind traditional notions of appropriateness as experienced in ELT [i.e., English language teaching] classrooms during secondary and tertiary education and adjusting their use of English to what is required and therefore "appropriate" in these professional communities. (Ehrenreich 2009: 146)

The importance of using community of practice as an organising concept, then, is in the opportunity it gives us to consider language and its regulation in relation to the practices of the community rather than in relation to some external conceptions of normativity. Ehrenreich's (2009) findings demonstrate the importance of learning to function in the specific community of practice in a way that is acceptable in that community. What is acceptable language is thus negotiated and defined in the community of practice.

Such negotiation of acceptable language forms part of what Hynninen (2013) calls language regulation. As discussed in more detail in Hynninen (2013; cf. Blommaert et al. 2009; Seargeant 2009), the concept of language regulation refers to the ways in which language users monitor and manage their own and others' language, whether locally (e.g., by correcting others' language in interaction) or institutionally (e.g., by establishing language policies or guidelines about acceptable usage). When developing relevant language learning and assessment goals, we may then want to take into account not only institutional language-regulatory practices but also local regulatory practices (e.g., who comments on language during interaction and can thus be seen to act as the language expert, and what

3 The concept of community of practice has been problematised by for instance Scollon (2001: 146), who argues that the problem with the concept lies in the difficulty of defining what constitutes a community of practice in the first place. I use the concept to emphasise the importance of contextualised language use - and to call for a more context-aware assessment framework. 
kind of language speakers correct in interaction) employed in communities of practice. Rather than automatically assume the relevance of set language standards, this paper suggests a focus on what is (made) relevant in communities of practice.

\section{The study: focus on the CEFR and metalingual commenting in ELF interaction}

The analysis proceeds in two stages. On the one hand, I focus on the relationship between language and culture in the CEFR by considering what types of contacts (particularly to what extent emphasis is placed on contacts between native and non-native speakers) and what kind of understanding of culture are articulated in the framework. This part of the analysis draws on Hynninen (2007). On the other hand, based on Hynninen (2013), I explore language regulation, or the ways speakers manage and monitor language, in ELF interaction (see metalingual commenting and accommodation below).

To capture how the relationship of language and culture is depicted in the CEFR, I first searched for all the occurrences of culture and cultural, along with all forms and combinations of mother tongue, language (including abbreviations such as L1), and words ending in lingual. In addition, I searched for words dealing with contacts (native, non-native, national, international, contact). I then used the word searches as the basis for a close analysis of the CEFR. In the close analysis, I particularly focused on the relationship between language and culture, and the types of contacts represented in the document, and analysed repeated ways of talking about the topics. This was done to consider the applicability of the document particularly to ELF contacts.

In order to better compare the findings of the CEFR analysis to ELF contacts, I further turned to ELF interaction data (see Hynninen 2013). These data were collected as part of the Studying in English as a Lingua Franca (SELF) project at the University of Helsinki, ${ }^{4}$ and include audio recordings of naturally occurring, English-medium seminar and group work sessions in the fields of biology and forestry at a major Finnish university. Several meetings from three different groups were recorded (in total, $20 \mathrm{~h} 35 \mathrm{~min}$ ). The participants (21 students and 5

4 The SELF project was directed by Prof. Anna Mauranen. It received funding from the University of Helsinki Research Funds for the three-year period of 2008-2010. For more information, see http://www.helsinki.fi/elfa/self (accessed 16 March 2014). 
subject teachers) were from different countries, and had various first languages (L1s), ${ }^{5,6}$ and thus when communicating in English, they were using the language as a lingua franca. All the recorded sessions were interactional in nature: in the seminar sessions, students gave presentations that were followed by discussion, and in the group work sessions, the students discussed and prepared a joint presentation for their course.

The analysis focuses on those parts of the English-medium interaction where language is taken up as a topic, that is, where metalingual (Berry 2005) commenting occurs. By metalingual commenting I mean overt references to and comments on both one's own and one's interlocutors' language (e.g., what's that in English). Metalingual comments thus direct the interactants' attention to language, and they often make explicit who intervenes or can intervene in language in interaction (e.g., who has the right to say that a chosen expression is "correct"), and also which norms of language the speakers draw on. They illustrate the relevance or irrelevance of established language standards for the purposes of the interaction (Hynninen 2013).

The questions "who intervenes" and "which norms are drawn on" are important in considering the division of speakers into NSs and non-native speakers (NNSs), and in deciding whose norms are relevant. In this sense metalingual comments also shed light on the question of language and culture, especially if approached from the perspective of who is seen to own the language (see Widdowson 1994). To further illustrate this changing role of NSs and NNSs in ELF, I will briefly consider accommodation practices in the ELF interaction data (for more detailed studies on accommodation in ELF, see, e.g., Jenkins 2000; Cogo and Dewey 2006; Cogo 2009). Accommodation (e.g., Giles et al. 1991; Gallois et al. 2005) illustrates how speakers recycle others' language, and thus sheds light on the ways that a co-interactant's language can influence a speaker's language. Speakers can either reuse language used by a co-interactant (i.e., accommodate to another speaker, also known as convergence) or reject the usage (i.e., either maintain their own speech habits or emphasise divergence from the interlocutor).

5 The participants' countries of origin were Brazil, Canada, Finland, Germany, Ghana, Portugal, Spain, the Sudan, and the USA; and their first languages were Arabic, Catalan, Dinka, English, Finnish, German, Portuguese, Spanish, Swedish, and Twi. One or two L1 speakers of English participated in each group.

6 I use the term first language (L1) to refer to a speaker's mother tongue, understood as a language (or languages) that the speaker has acquired in childhood. The term second language (L2) is used as an umbrella term to refer to any language a speaker has learned in addition to his or her first language(s). An L1 speaker, then, is a native speaker, and an L2 speaker a non-native speaker. 
Together the metalingual commenting and accommodation in the ELF interaction are meant to illustrate the (in)applicability of the CEFR in ELF contexts.

\section{The analyses: comparisons of the findings}

This section brings together the findings of the CEFR and the ELF interaction analyses. Section 5.1 begins with a brief overview of the types of contacts emphasised in the CEFR (based on the word search), followed by a more detailed analysis of some of the instances. I then introduce examples from the ELF interaction analysis to compare the assumptions in the CEFR with language use in the ELF interaction. Section 5.2 discusses repeated ways of talking about language and culture in the CEFR, first by considering the word search, and then by looking at individual instances. The section further compares the findings to the metalingual commenting in the ELF interaction. Both sections end with a discussion of the findings, the implications of which are further discussed in Section 6.

\subsection{Types of contacts: the NS-NNS axis}

From an ELF perspective, one important aspect to focus on in the CEFR are the types of contacts relevant in the document (Hynninen 2007). By looking at the number of occurrences for the term native speaker(s) as opposed to non-native speaker(s) in Table 1, we can get an idea of the relevance of the NS in the CEFR.

Out of the 44 occurrences of native speaker(s), 19 were in the descriptors, which also included two occurrences of native speed. Otherwise, native occurred once in the combination native norms, and 13 times in the combination of native language, as opposed to 3 occurrences of non-native language. While the numbers do not in themselves reveal much about the types of contacts focused on in the

Table 1: Number of occurrences of native speaker(s) and non-native speaker(s) in the CEFR*.

\begin{tabular}{ll}
\hline Term & No. of occurrences \\
\hline native speaker(s) & 44 \\
non-native speaker(s) & 1 \\
non-native and native speaker & 1 \\
native or non-native person & 1
\end{tabular}

* The calculations do not include the contents page, bibliography, or appendices. Note that the table also includes one instance of "native or non-native person." 
CEFR, the scarcity of references to non-native speaker(s) as opposed to the references to native speaker(s) implies the relevance of NS contacts.

If we take a closer look at how the term "native speaker(s)" is used in the CEFR, we can see the emphasis on NS-NNS contacts, particularly in the descriptors. For instance, descriptors for the highest level C2 include the following (relevant bits in bold font):

(1) a. Can understand any native speaker interlocutor (Europe 2001: 75; level C2)

b. Can hold his/her own in formal discussion [...] at no disadvantage to native speakers. (Europe 2001: 78; level C2)

c. Appreciates fully the sociolinguistic and sociocultural implications of language used by native speakers and can react accordingly. (Europe 2001: 122; level C2)

A further example from another descriptor level implies the same NS focus:

(2) Can interact with a degree of fluency and spontaneity that makes regular interaction with native speakers quite possible without strain for either party. (Europe 2001: 24, 27, 129; level B2)

It then appears that the reference scales place NS competence as the highest form of language competence. Considering the language-independent focus of the CEFR, the emphasis on NS-NNS contacts may not be surprising, but it is worth looking into more detail what the quotations suggest about the relationship of the NNS and the NS. We can see in examples (1) and (2) that the focus is on accommodating the NS. What the quotations further suggest is that the language learner or the second language (L2) speaker is seen as the one who needs to adapt to the NS interlocutor and what we could call native conventions of using the language (see also McNamara 2012). The expectation is that the L2 speaker does all the work, even if there are at least two parties in interaction.

That interaction is a joint effort is obviously true for all languages, not just for English used as a lingua franca, and considering that the descriptors in the CEFR are aimed at individuals, we might argue that including an interactional focus in the descriptors is unreasonable. Similarly, we might say that the NS is used in the CEFR as a necessary idealisation of a successful communicator. However, if we want to develop assessment criteria based on research on language and interaction (see, e.g., Hulstjin 2007), it is important to consider to what extent the descriptors reflect the findings of how people actually use language. For instance, Pilkinton-Pihko (2013: 86-102) has shown that some of the descriptors for spoken 
language in the CEFR seem to be geared more towards written language, and do not take into account normal dysfluences in spoken language. From the perspective of ELF communication, we also need to question the use of the NS as a point of reference, not only because ELF communication takes place in settings where NSs may not be present, but also because the term belongs to a paradigm that views communicative success in relation to such target proficiency that does not seem to ensure communicative success in ELF interaction (see, e.g., Jenkins 2000; Hülmbauer 2009).

What is notable, though, is that while the CEFR descriptors focus on the NSNNS axis, an attempt is made in the CEFR to move away from seeing the NS as a point of comparison. In the document, level $\mathrm{C} 2$ is described as follows:

(3) Level C2, whilst it has been termed 'Mastery', is not intended to imply nativespeaker or near native-speaker competence. What is intended is to characterise the degree of precision, appropriateness and ease with the language which typifies the speech of those who have been highly successful learners. (Europe 2001: 36)

The question that arises - and remains unanswered - is what characterises a "highly successful" language learner? Considering the NS focus in the descriptors, it seems that the difficulty in moving away from the NS model relates to the lack of clear descriptions of what characterises successful language use - and language users. This is a fundamental question that concerns language learning irrespective of the target language.

However, the question is further complicated when a language is used as a lingua franca. Lingua franca use means a shift from the NS-NNS axis to mainly NNS-NNS contacts, which means that the question of successful language use needs to be seen from the perspective of what characterises successful communication in situations where most (or all) of the speakers are NNSs, and where NSs may not play a role at all. While we may assume the relevance of NSs in determining what counts as successful language use in NS-NNS contacts, we could then claim that in lingua franca interaction it is not self-evident who can act as the gatekeeper for "good" language. For instance, Hülmbauer (2009) has suggested that in ELF interaction, drawing on analogies from other shared languages, as well as the use of non-standard forms, may actually enhance rather than hinder communicative success. In addition, several ELF studies have reported on the importance of mutual accommodation (e.g., Jenkins 2000; Deterding and Kirkpatrick 2006; Cogo and Dewey 2006; Cogo 2009), which, as we can see from the example below, can also involve NSs of English adopting unconventional usage. In the example, which comes from my ELF interaction data, from a student group 
work setting, NS3 (L1 American English) accommodates to S2's (L1 Brazilian Portuguese) use of the unconventional expression study case.

(4) (Hynninen 2013: 156)

S2: <FIRST NAME NS3> do you think we need to to find more information about the traditional methods or it's okay from this study case,

NS3: er, i think it will maybe be okay from the study case i can maybe do some explaining er a little further than what the study case says

S2: mhm-hm

NS3: but i think they'll mention maybe some traditional previously at least traditional methods as well so

In example (4), S2 asks NS3 for his opinion about the need to find more information about the topic the group is working with. We can see that NS3 recycles not only the unconventional expression (study case) used by S2, but also a grammatical construction (it's okay from this study case becomes be okay from the study case) and another expression (traditional methods). This kind of alignment increases explicitness in talk, which in effect increases communicative effectiveness. In addition, since an unconventional form is recycled, the example further points towards the possibility of ELF interaction moving beyond ENL norms (see also Hülmbauer 2009; Mauranen 2012: 48-52).

What we also know from ELF research is that the roles of NSs and NNSs in ELF interaction seem to be different compared to those in interaction between L1 and L2 speakers: in L1-L2 interaction, language corrections have been found to be done by NSs only (e.g., Brouwer et al. 2004; Kurhila 2006), whereas in ELF interaction, NNSs of English have been found to take on the role of language regulators even when NSs of English are present (Smit 2010: Ch 7; Hynninen 2012, 2013). This suggests reduced importance of the NS-NNS distinction in ELF interaction. ${ }^{7}$ Example (5) below is a case in point. It involves two university teachers, both L2 speakers of English (T1 is an L1 speaker of Finnish and T2 a bilingual in Swedish and Finnish), interacting in an English-medium instructional context. It starts with $\mathrm{T} 1$ commenting on a term (palmetto, used by a student in her written report) that he does not recognise to be English. After that, T2 comments on the previous comment, and at the same time, takes on an agentive role as the regulator of language.

7 The importance of the NS-NNS distinction may of course vary from one ELF context to another. To what extent the importance is reduced in ELF interaction in general is an empirical question. 
(5) (Hynninen 2013: 116)

T1: ((...)) and try to refer to to try to utilise the standard standard terms in in er er as they are in english. er jaa another term that was is here in page 11 er up er there you use the word palmetto i don't know whether this is something derived from spanish or or i guess so but er

T2: but bu- could i [explain more]

T1: [yes please]

T2: palmetto is also an english word nowadays

T1: is it

T2: it has been adopted in the english language and and it refers to to to (it is) it should read here the (terminal) bud actually it's a bud but it's very (destructive) because when you take the bud the tree will die so you get this er piece of edible food and then the whole tree dies so many palms can be used for palmetto an- and it's it's very it's used as as salad and there are even some other palms that are much more er used for that particular purpose but especially in american english that word is [now] $<\mathrm{T} 1>[\mathrm{mhm}]</ \mathrm{T} 1>$ er now common.

T1: er, er yes then er, some usual comments er on the use of references $((.)$.

The example illustrates negotiation of the boundaries between English and other languages. The two teachers have different views about the word palmetto, T1 criticising the student for using the non-English word (derived from Spanish), and T2 stating that the word is common in American English. What we can see is that T2 draws on his understanding of contemporary use of American English in justifying the inclusion of the word in the lexicon of acceptable English words, and that he thus regulates language by resorting to his familiarity of contemporary use of American English. Particularly in terms of deciding on acceptable vocabulary, it has also been shown that content expertise plays an important role (Smit 2010: Ch 7; see also Hynninen 2013).

In sum, particularly the CEFR descriptors incorporate the assumption of NSs as models for language learning, as well as the idea of non-reciprocal interaction where the NNS is the one who adapts. The examples of ELF interaction, supported by previous ELF studies, on the other hand, illustrate the reduced importance of the NS-NNS divide. While the language regulation may still follow the L2 speaker's conception of) what is "correct" in ENL, it is important to note the readiness of the L2 speakers to take on the role of language regulator (example [5] above; see also Hynninen 2012, 2013). This is also where we see the NS ownership of English (Widdowson 1994) crumble. 


\subsection{The target culture}

Another aspect of the CEFR relevant to the discussion here is the way culture is talked about in the document (Hynninen 2007). If we take a look at a selection of terms related to language and culture used in the CEFR (see Table 2), we can notice some preference patterns.

Table 2: Selected terms used in the CEFR*.

\begin{tabular}{lclc}
\hline Language & No. of occurrences & Culture & No. of occurrences \\
\hline multilingual(ism) & 5 & multicultural & 2 \\
bilingual(ism) & 7 & intercultural(ity) & 26 \\
monolingual & 6 & sociocultural(ly) & 27 \\
plurilingual(ism) & 55 & pluricultural(ism) & 38 \\
\hline
\end{tabular}

* The calculations do not include the contents page, bibliography, or appendices.

What is obvious is the frequency of the terms plurilingual(ism) (55) and pluricultural(ism) (38), especially in relation to the terms multilingual(ism) (5) and multicultural (2). In the CEFR, the former terms refer to the ability of individuals to use different languages and to relate to different cultures; these terms also cover partial competencies that reject the native ideal (Europe 2001: 3-4, 135; Bailly et al.2003: 39-40). The latter terms, on the other hand, are used to refer to the coexistence of several languages and cultures in a society and to knowledge of several languages (Europe 2001: 3-4; Bailly et al. 2003: 39-40). That the terms plurilingual(ism) and pluricultural(ism) are used notably more often than multilingual(ism) and multicultural can be explained by the CEFR's focus on individuals' language proficiency, but it also shows that the document encourages individuals to learn (about) several languages and cultures.

In general, culture is often mentioned in relation to language, and the two are seen to be interconnected, as illustrated in example (6).

(6) a. Language is not only a major aspect of culture, but also a means of access to cultural manifestations. (Europe 2001: 6)

b. ... in his or her mother tongue and the associated culture (Europe 2001: 43)

As the above instances show, language is considered a part of culture and a way to access culture. It is thus not surprising that the lemmas CULTURE and CULTURAL are often coupled with the lemmas LANGUAGE and LINGUAL, common 
pairs being language(s) and [...] culture(s) (15) and plurilingual(ism) and pluricultural(ism) (31). The interconnectedness of culture and language in the CEFR supports the interpretation made in Section 5.1 that NS contacts are highlighted in the document. When language is further approached as manifestation of a particular culture of NSs, it is not surprising if the NS becomes the point of comparison for language learning.

However, as illustrated in the following example (7), it remains somewhat unclear what exactly is meant by culture in the CEFR (see Hynninen 2007: 31):

(7) a. ... cultural characteristics of the foreign country (Europe 2001: 135)

b. ... the various cultures (national, regional, social) to which that person has gained access (Europe 2001: 6)

c. Good knowledge of the culture of a community (Europe 2001: 133)

d. The features distinctively characteristic of a particular European society and its culture may relate, for example, to: 1. Everyday living [... . 2. Living conditions [...] 3. Interpersonal relations [...] 4. Values, beliefs and attitudes [...] 5. Body language [...] 6. Social conventions [...] 7. Ritual behaviour (Europe 2001: 102-103)

e. ... cuisine and eating habits of the particular foreign culture (Europe 2001: 138)

The above instances show that in the CEFR, culture is an all-encompassing concept that can be used in relation to different geographical areas and communities associated with a particular language. Considering the characteristics of a culture given in examples (6) and (7), it appears that culture refers to different aspects related to living in a particular community. Despite the ambiguity in the meaning of culture, in all, it appears that the CEFR reproduces the idea that each language represents a particular NS culture (see also Pilkinton-Pihko 2013: 159160).

From a lingua franca perspective, the foci in the CEFR on NS culture and on the interconnectedness of language and culture are problematic. For a language used as a lingua franca, we can no longer assume as strong a connection between the language and its NS community or communities (Meierkord 2002; Baker 2009). This is bound to have consequences in terms of how the language is used - and ultimately what characterises successful communication. What ELF interactions can teach us is the importance of negotiation of acceptability in the course of interaction as opposed to taking codified ENL standards as the assumed yardstick (see, e.g., Jenkins 2000; Mauranen 2012). The following example (8), taken from an ELF interaction, suggests that, at least to some extent, ELF speakers are moving away from a reliance on what they consider to be customary in ENL 
communities - and that this can also be a conscious choice. The ELF speaker in the extract is the same T2 as in example (5) (a teacher in forestry, L1s Swedish and Finnish).

(8) (Hynninen 2013: 117)

T2: and let's take a little er but important le- language thing you have the date on the first page so please use the international way of writing dates 26 february 2008 that is not english that's not ame- that's not british that's not american but that's the international standard no no 26th no T-H there but 26 february 2008 that is used by the united nations like this nothing else so so i i i i just repeat it is not the standard in any existing language but that is (the) international standard in official documents and we can well adopt it

The example illustrates how the speaker recommends that the students adopt what he calls "the international way of writing dates". What is notable, again, is that the person recommending that the international standard be adopted is a NNS of English, who in effect acts as the language regulator (see Smit 2010: Ch 7; Hynninen 2012, 2013). The suggestion in the example to rely on international conventions also implies that the term "culture" receives a new meaning as the culture of the ELF community of practice - here seen as part of the international community (cf. Baker 2009).

Even if the CEFR seems to highlight NS-NNS contacts, especially in the descriptors, the notions of plurilingual and pluricultural resources often referred to in the document deserve some more attention. The idea behind the notions is that speakers' linguistic and cultural resources are always partial, or as Blommaert (2010) puts it, truncated. For instance, we may be able to use one language fluently for casual conversation, but struggle when writing in it, and be able to understand complex texts written in another language, but struggle when expressing ourselves in speech. In the CEFR, we are encouraged to acknowledge these partial competencies, and to use them in interaction (Europe 2001: 135). What is surprising, though, is that this idea is not conveyed in the descriptors, which, as we have seen, rely on NS-NNS contacts, and seemingly, on a monolingual ideal.

One way to develop the descriptors, then, could be to remodel them with a plurilingual person in mind (cf. Pilkinton-Pihko 2013: 102). In addition to the readiness of L2 speakers to act as language regulators in ELF interaction, what ELF research has shown is that, at least in more casual conversation, plurilingual resources, such as code switching, transfer phenomena, and the use of cognates, are exploited to achieve mutual understanding (Hülmbauer 2009; Kalocsai 2009). Chances are that this usage influences speakers' views of acceptable language, 
and also reduces the weight we sometimes attach to the "purity" of the languages we use.

\section{Conclusions: moving beyond NS-NNS contacts and towards more context-aware assessment}

This paper has discussed the CEFR from the perspective of ELF research. It has illustrated the NS and target culture foci of the CEFR, and how these aspects are problematic from an ELF perspective. By analysing ELF data, the paper has argued for the importance of focusing on what speakers of ELF treat as acceptable or unacceptable English when actually using the language. The idea has been to illustrate how such a bottom-up approach can be used to predict changes in the language norms speakers attach to (the use of) English, and how such an approach is crucial in reconsidering models for English language teaching and testing.

Considered from an ELF perspective, the findings illustrate the problematic nature of the focus on NS contacts in the CEFR. The analysis of ELF interaction implies that we are not just dealing with a question of frequency of English NNSNNS contacts as opposed to English NS-NNS contacts, but the reduced importance of the NS-NNS division in ELF interaction: NNSs act as language regulators even when NSs are present (Hynninen 2012, 2013). This readiness to take on the role of a language expert, along with previous descriptive studies on ELF that have illustrated independence of ELF users from ENL and English NS cultural norms (e.g., Baker 2009; Hülmbauer 2009; Seidlhofer 2011) calls into question NS ownership of English.

Traditionally, NSs of English have been treated as the legitimate owners of English (e.g., Quirk 1990; Trudgill 2002), but it has also been suggested that NNSs of English can claim ownership of the language (Kachru 1996; Jenkins 2000; Seidlhofer 2011). The question of ownership is central in considering who (or what) ELF users see as authorities of acceptable English on the one hand, and correct English on the other. The findings of this study suggest that ELF users to some extent accept alternative sources to English NSs and ENL when negotiating acceptability (see also Hülmbauer 2009; Mauranen 2012: 48-52; Hynninen 2013; Pilkinton-Pihko 2013: Ch 7), which can be seen as the first step to legitimising ELF.

As to how culture is approached in the CEFR, the findings show that the framework is not explicit in defining what culture means, but the target culture focus of the CEFR seems to rely on the idea of linking a nation-state and "its" language together (see also Pilkinton-Pihko 2013: 159-160). It is questionable 
whether such a monolithic view of culture reflects the reality in any community, NS or otherwise, but the problematic nature of the view becomes particularly evident in ELF interaction (e.g., Baker 2009). As the examples of ELF interaction in this paper have illustrated, the findings suggest the increased importance of approaching the language learning dimension in relation to ELF use in specific contexts (see also Ehrenreich 2009). The question we need to investigate further is what kind of language has consequences for the speaker; that is, what kind of language is treated by ELF users (in communities of practice) as unacceptable versus acceptable, or indeed, incorrect versus correct?

In all, the findings imply that if we want to incorporate the construct of ELF communication into assessment of English, as McNamara (2012) suggests, we need to reconsider some of the fundamental assumptions of language use presented in the CEFR, particularly in the descriptors. First, we need to move beyond NS-NNS contacts and the idea of a NS target culture (see also Seidlhofer 2003; Leung 2013; Pilkinton-Pihko 2013). We have seen from the examples of ELF interaction the agentive role of ELF speakers and the use of alternative norms for defining acceptability, which illustrate the distinctiveness of ELF interaction. This point is further supported by previous research on ELF (e.g., Hülmbauer 2009; Smit 2010; Mauranen 2012; Hynninen 2013). In effect, we could describe ELF encounters as intercultural encounters where interactants move towards each other reaching for a so-called inter-space (Kaikkonen 2000: 50; see also House 2000: 43-44), possibly creating what Kramsch (1996) has called a "third culture," or a space between a person's own and his or her interlocutors' culture(s) (see Baker 2009). The CEFR and particularly its descriptors, where the NNS is expected to adapt to the language and culture of the NS, then, is ill-suited to be applied for in ELF situations, and it seems clear that we need to develop new descriptors, possibly a new framework altogether, to address the questions raised by lingua franca interaction.

Second, it would be useful to adopt a more diversified view of language users compared to the monolithic NS and the eternal language learner suggested particularly in the CEFR descriptors. One way of addressing this issue would be to focus on how people actually use and also regulate language in different situations, and to develop more context-aware descriptors based on such research. The examples of ELF interaction in this paper support the relevance of considering language use and language regulation in specific contexts (see also Ehrenreich 2009; Kalocsai 2009; Smit 2010). While the community of practice approach taken in this study may not be applicable for all ELF contexts, by taking community of practice as an organising concept, we can address at least some of the challenges McNamara (2012) envisions for ELF research. That is, we can see what is (or emerges as) acceptable language for actual users of ELF and in effect as the 
de facto norms we may then be able to use in assessing the success of ELF communication. In addition, we can approach the learning dimension in ELF in relation to more concrete and contextualised interactional goals than what would be possible otherwise. The study, then, calls for further studies that would consider the functions of - and reasons for - different types of language regulation across ELF communities of practice. This would include considering the relationships between language-regulatory practices in interaction, and language regulation "imposed" on speakers in the form of established language standards.

\section{Appendix: transcription conventions}

The transcriptions are based on a slightly modified version of the SELF project transcription guide (see http://www.helsinki.fi/elfa/self). Special symbols used in this paper are explained below.

Speaker codes:

$\begin{array}{ll}\text { S\# } & \text { Student } \\ \text { NS\# } & \text { Student (NS of English) } \\ \text { T\# } & \text { Teacher }\end{array}$

Transcription symbols:

\begin{tabular}{|c|c|}
\hline & Brief pause $2-3$ sec. \\
\hline & Pause 3-4 sec. \\
\hline te- & Unfinished utterances \\
\hline [text 1] [text 2] & $\begin{array}{l}\text { Overlapping speech (approximate, shown to the nearest word, } \\
\text { words not split by overlap tags) }\end{array}$ \\
\hline C-A-P-S & Capital letters when words spelled out and for acronyms \\
\hline ext) & Uncertain transcription \\
\hline ;\#> text $</$ S\#> & Back-channelling when marked within another speaker's turn \\
\hline JAME S\#> & Names of participants in the same speech event \\
\hline ..)) & Omitted text from transcription \\
\hline
\end{tabular}

\section{References}

Alderson, J. Charles. 2007. The CEFR and the need for more research. The Modern Language Journal 91. 659-663.

Bailly, Sophie, Sean Devitt, Marie-José Gremmo, Frank Heyworth, Andy Hopkinds, Barry Jones, Mike Makosch, Philip Riley, Gé Stoks \& John Trim (eds). 2003. Common European 
framework of reference for languages: Learning, teaching, assessment. A guide for users. Strasbourg: Council of Europe.

Baker, Will. 2009. The cultures of English as a lingua franca. TESOL Quarterly 43(4). 567-592. Berry, Roger. 2005. Making the most of metalanguage. Language Awareness 14(1). 3-20. Björkman, Beyza. 2008. English as the lingua franca of engineering: The morphosyntax of academic speech events. Nordic Journal of English Studies 7(3). 103-122.

Björkman, Beyza (ed.). 2011. English as a lingua franca. [Special issue]. Journal of Pragmatics 43(4).

Björkman, Beyza. 2013. English as an academic lingua franca (Developments in English as a Lingua Franca 3). Berlin \& New York: Mouton De Gruyter.

Blommaert, Jan. 2010. The sociolinguistics of globalization. Cambridge: Cambridge University Press.

Blommaert, Jan, Helen Kelly-Holmes, Pia Lane, Sirpa Leppänen, Máiréad Moriarty, Sari Pietikäinen \& Arja Piirainen-Marsh. 2009. Media, multilingualism and language policing: An introduction. Language Policy 8. 203-207.

Brouwer, Catherine E., Gitte Rasmussen \& Johannes Wagner. 2004. Embedded corrections in second language talk. In Rod Gardner \& Johannes Wagner (eds), Second language conversations, 75-92. London: Continuum.

Byrnes, Heidi. 2007. Developing national language education policies: Reflections on the CEFR. The Modern Language Journal 91. 679-685.

Carey, Ray. 2013. On the other side: Formulaic organizing chunks in spoken and written academic ELF. Journal of English as a Lingua Franca 2(2). 207-228.

Cogo, Alessia. 2009. Accommodating difference in ELF conversations: A study of pragmatic strategies. In Anna Mauranen \& Elina Ranta (eds), English as a lingua franca: Studies and findings, 254-273. Newcastle upon Tyne: Cambridge Scholars.

Cogo, Alessia \& Martin Dewey. 2006. Efficiency in ELF communication: From pragmatic motives to lexico-grammatical innovation. In Anna Mauranen \& Maria Metsä-Ketelä (eds), English as a Lingua Franca. [Special issue]. Nordic Journal of English Studies 5(2). 59-93.

Cogo, Alessia \& Martin Dewey. 2012. Analysing English as a lingua franca: A corpus-driven investigation. London: Continuum.

Deterding, David \& Andy Kirkpatrick. 2006. Emerging South-East Assian Englishes and. intelligibility. World Englishes 25(3/4). 391-409.

Dewey, Martin. 2009. English as a lingua franca: Heightened variability and theoretical implications. In Anna Mauranen \& Elina Ranta (eds), English as a lingua franca: Studies and findings, 60-83. Newcastle upon Tyne: Cambridge Scholars.

Ehrenreich, Susanne. 2009. English as a lingua franca in multinational corporations - Exploring business communities of practice. In Anna Mauranen \& Elina Ranta (eds), English as a lingua franca: Studies and findings, 126-151. Newcastle upon Tyne: Cambridge Scholars.

Europe, Council of. 2001. Common European Framework of Reference for language learning and teaching. Cambridge: Cambridge University Press.

Fulcher, Glenn. 2004. Deluded by artifices? The common European framework and harmonization. Language Assessment Quarterly 1(4). 253-266.

Gallois, Cindy, Tania Ogay \& Howard Giles. 2005. Communication accommodation theory. A look back and a look ahead. In William B. Gudykunst (ed.), Theorizing about intercultural communication, 121-148. London: Sage.

Giles, Howard, Nikolas Coupland \& Justine Coupland. 1991. Accommodation theory: Communication, context, and consequence. In Giles Howard, Justine Coupland \& Nikolas 
Coupland (eds), Contexts of accommodation, 1-68. Cambridge: Cambridge University Press.

Graddol, David. 2006. English next. Why global English may mean the end of "English as a foreign language". London: British Council.

Haberland, Hartmut. 2011. Ownership and maintenance of a language in transnational use: Should we leave our lingua franca alone? In Beyza Björkman (ed.), English as a lingua franca. [Special issue]. Journal of Pragmatics 43(4). 937-949.

House, Juliane. 2000. Zur Rolle kommunikativ-interkultureller Bewußtheit beim

Fremdsprachenerwerb [On the role of communicative-intercultural awareness in second language acquisition]. In Pauli Kaikkonen \& Viljo Kohonen (eds), Minne menet, kielikasvatus? Näkökulmia kielipedagogiikkaan [Where are you headed, language education? Perspectives on language pedagogy], 27-47. Jyväskylä: University of Jyväskylä.

House, Juliane. 2003. English as a lingua franca: A threat to multilingualism? Journal of Sociolinguistics 7(4). 556-578.

Hülmbauer, Cornelia. 2009. “We don't take the right way. We just take the way we think you will understand" - The shifting relationship between correctness and effectiveness in ELF. In Anna Mauranen \& Elina Ranta (eds), English as a lingua franca: Studies and findings, 323-347. Newcastle upon Tyne: Cambridge Scholars.

Hulstijn, Jan H. 2007. Dimensions of language proficiency. The Modern Language Journal 91. 663-667.

Hynninen, Niina. 2007. Cultural discourses in CEF: How do they relate to ELF? Helsinki: University of Helsinki MA thesis. http://urn.fi/URN:NBN:fi-fe20071156 (accessed 13 April 2014).

Hynninen, Niina. 2012. ICL at the micro level: L2 speakers taking on the role of language experts. In Ute Smit \& Emma Dafouz Milne (eds), Integrating content and language in higher education. [Special issue]. AlLA Review 25. 13-29.

Hynninen, Niina. 2013. Language regulation in English as a lingua franca. Exploring languageregulatory practices in academic spoken discourse. Helsinki: University of Helsinki dissertation. http://urn.fi/URN:ISBN:978-952-10-8639-7 (accessed 13 April 2014).

Jenkins, Jennifer. 2000. The phonology of English as an international language. 0xford: Oxford University Press.

Jenkins, Jennifer. 2007. English as a lingua franca: Attitude and identity. Oxford: Oxford University Press.

Jenkins, Jennifer, Alessia Cogo \& Martin Dewey. 2011. Review of developments in research into English as a lingua franca. Language Teaching 44(3). 281-315.

Kachru, Braj B. 1996. Opening borders with world Englishes: Theory in the classroom. In Steve Cornwell, Peggy Rule \& Toshiko Sugino (eds), On JALT96: Crossing borders. The proceedings of the $23 \mathrm{rd}$ annual JALT international conference on language teaching/ learning, Hiroshima, Japan, November 1996, 10-20. Tokyo: JALT.

Kaikkonen, Pauli. 2000. Autenttisuus ja sen merkitys kulttuurienvälisessä vieraan kielen opetuksessa [Authenticity and its role in intercultural foreign language teaching]. In Pauli Kaikkonen \& Viljo Kohonen (eds), Minne menet, kielikasvatus? Näkökulmia kielipedagogiikkaan [Where are you headed, language education? Perspectives on language pedagogy], 49-61. Jyväskylä: University of Jyväskylä.

Kalocsai, Karolina. 2009. Erasmus exchange students: A behind-the-scenes view into an ELF community of practice. Apples - Journal of Applied Language Studies 3(1). 25-49. 
Kankaanranta, Anne \& Leena Louhiala-Salminen. 2010. “English? - Oh, it’s just work!”: A study of BELF users' perceptions. English for Specific Purposes 29(3). 204-209.

Kramsch, Claire. 1996. Context and culture in language teaching. Oxford: Oxford University Press.

Kurhila, Salla. 2006. Second language interaction. Amsterdam \& Philadelphia: John Benjamins. Lave, Jean \& Etienne Wenger. 1991. Situated learning: Legitimate peripheral participation. Cambridge: Cambridge University Press.

Leung, Constant. 2013. The "social" in English Language Teaching: Abstracted norms versus situated enactments. JELF 2(2). 283-313.

Little, David. 2007. The common European framework of reference for languages: Perspectives on the making of supranational language education policy. The Modern Language Journal 91. 645-655.

Mauranen, Anna. 2007. Hybrid voices: English as the lingua franca of academics. In Kjersti Fløttum (ed.), Language and discipline perspectives on academic discourse, 243-259. Newcastle: Cambridge Scholars.

Mauranen, Anna. 2009. Chunking in ELF: Expressions for managing interaction. Intercultural Pragmatics 6(2). 217-233.

Mauranen, Anna. 2010. Features of English as a lingua franca in academia. In Anna Mauranen \& Niina Hynninen (eds), English as a lingua franca. [Special issue]. Helsinki English Studies 6. 6-28.

Mauranen, Anna. 2012. Exploring ELF. Academic English shaped by non-native speakers. Cambridge: Cambridge University Press.

McNamara, Tim. 2012. English as a lingua franca: The challenge for language testing. JELF1(1). 199-202.

Meierkord, Christiane. 2002. “Language stripped bare” or “linguistic masala”? Culture in lingua franca communication. In Karlfried Knapp \& Christiane Meierkord (eds), Lingua franca communication, 109-134. Frankfurt am Main: Peter Lang.

Metsä-Ketelä, Maria. 2006. "Words are more or less superfluous": The case of more or less in academic lingua franca English. In Anna Mauranen \& Maria Metsä-Ketelä (eds), English as a lingua franca. [Special issue]. Nordic Journal of English Studies 5(2). 117-143.

North, Brian. 2007. The CEFR illustrative descriptor scales. The Modern Language Journal 91. 656-659.

Pennycook, Alastair. 2012. Lingua francas as language ideologies. In Andy Kirkpatrick \& Roland Sussex (eds), English as an international language in Asia: Implications for language education, 137-156. Dordrecht: Springer.

Pilkinton-Pihko, Diane. 2013. English-medium instruction: Seeking assessment criteria for spoken professional English. Helsinki: University of Helsinki dissertation. http://urn.fi/URN:ISBN:978-952-10-9520-7 (accessed 13 April 2014).

Pitzl, Marie-Luise. 2009. "We should not wake up any dogs": Idiom and metaphor in ELF. In Anna Mauranen \& Elina Ranta (eds), English as a lingua franca: Studies and findings, 298-322. Newcastle upon Tyne: Cambridge Scholars.

Pitzl, Marie-Luise. 2012. Creativity meets convention: Idiom variation and re-metaphorization in ELF. Journal of English as a Lingua Franca 1(1). 27-55.

Quirk, Randolph. 1990. Language varieties and standard language. English Today 6(1). 3-10.

Ranta, Elina. 2009. Syntactic features in spoken ELF - Learner language or spoken grammar? In Anna Mauranen \& Elina Ranta (eds), English as a lingua franca: Studies and findings, 84-106. Newcastle upon Tyne: Cambridge Scholars. 
Ranta, Elina. 2010. English in the real world vs. English at school - Finnish English teachers' and students' views. International Journal of Applied Linguistics 20(2). 156-177.

Ranta, Elina. 2013. Universals in a universal language? - Exploring verb-syntactic features in English as a lingua franca. Tampere: University of Tampere dissertation. http://urn.fi/URN:ISBN:978-951-44-9299-0 (accessed 13 April 2014).

Scollon, Ron. 2001. Mediated discourse. The nexus of practice. London: Routledge.

Seargeant, Philip. 2009. Language ideology, language theory, and the regulation of linguistic behaviour. Language Sciences 31. 345-359.

Seidlhofer, Barbara. 2003. A concept of international English and related issues: From "real English" to "realistic English"? Strasbourg: Council of Europe.

Seidlhofer, Barbara. 2004. Research perspectives on teaching English as a lingua franca. Annual Review of Applied Linguistics 24. 209-239.

Seidlhofer, Barbara. 2007. English as a lingua franca and communities of practice. In Sabine Volk-Birke \& Julia Lippert (eds), Anglistentag 2006 Halle proceedings, 307-318. Trier: Wissenschaftlicher Verlag.

Seidlhofer, Barbara. 2009. Common ground and different realities: World Englishes and English as a lingua franca. World Englishes 28(2). 236-245.

Seidlhofer, Barbara. 2011. Understanding English as a Lingua Franca. Oxford: Oxford University Press.

Smit, Ute. 2010. English as a lingua franca in higher education. A longitudinal study of classroom discourse. Berlin \& New York: Mouton de Gruyter.

Toepfer, Tom \& Anu Virkkunen-Fullenwider. 2005. Introduction of CEF as a tool for evaluation, and training of teachers in its use. Paper presented at the CercleS workshop, University of Helsinki Language Centre, 31 August. http://www.helsinki.fi/kksc/cef2005/documents/ ToepferVirkkunen.pdf (accessed 13 April 2014).

Trudgill, Peter. 2002. Sociolinguistic variation and change. Edinburgh: Edinburgh University Press.

Wenger, Etienne. 1998. Communities of practice: Learning, meaning, and identity. Cambridge: Cambridge University Press.

Widdowson, Henry G. 1994. The ownership of English. TESOL Quarterly 28(2). 377-389.

\section{Bionote}

Niina Hynninen's background is in ethnographically-informed discourse studies and ELF. She conducted her doctoral studies at the University of Helsinki, and received her doctoral degree in 2013. For a year and a half, Hynninen worked as a temporary, full-time lecturer at the Department of English, Stockholm University, before returning to the Department of Modern Languages, University of Helsinki, as a post doc researcher. Hynninen's research interests include academic discourse, normativity in language, and ELF.

Note: This paper was partly produced when the author was employed as a lecturer at the Department of English at Stockholm University. 